\title{
Pemeriksaan Kadar Hemoglobin dengan Metode POCT (Point of Care Testing) sebagai Deteksi Dini Penyakit Anemia Bagi Masyarakat Desa Sumbersono, Mojokerto
}

\author{
Examination of Hemoglobin Levels with POCT (Point of Care Testing) Method as \\ Early Detection of Anemia Disease For Community in Sumbersono Village, \\ Mojokerto
}

\author{
Ersalina Nidianti ${ }^{1}$, Gilang Nugraha ${ }^{2}$, Ilmiah Alvi Nisa Aulia ${ }^{3}$, \\ Saumia Khoirunnisa Syadzila ${ }^{4}$, Sri Surya Suciati ${ }^{5}$, Nila Dwi Utami ${ }^{6}$ \\ ${ }^{1,2,3,4,5}$ Analis Kesehatan, Universitas Nahdlatul Ulama Surabaya, Indonesia \\ ersalinanidianti@,unusa.ac.id
}

Riwayat Artikel: Dikirim 5 Agustus 2019; Diterima 18 November 2019; Diterbitkan 30 November 2019

\begin{abstract}
Abstrak
Kasus anemia di Indonesia masih cukup tinggi hasil menunjukkan bahwa angka prevalensi anemia secara nasional pada semua kelompok umur adalah 21,70\%. Sedangkan prevalensi anemia di Provinsi Jawa Timur sebesar 5,8 \%. Anemia adalah kondisi penyakit dimana jumlah sel darah merah lebih rendah dari jumlah normal. Kondisi ini biasa disebut sebagai kekurangan darah. Anemia dapat dideteksi dengan melakukan pengukuran kadar hemoglobin ( $\mathrm{Hb}$ ) menggunakan metode POCT (Point of Care Testing). Metode POCT merupakan metode yang dilakukan untuk pemeriksaan sederhana dengan menggunakan sampel dalam jumlah sedikit, mudah, cepat serta efektif dilakukan di daerah-daerah dengan jumlah fasilitas kesehatan seperti pusat kesehatan masyarakat (puskesmas), rumah sakit yang relatif sedikit khususnya di lokasi pengabdian masyarakat di Desa Sumbersono, Mojokerto. Jenis metode yang digunakan adalah observasional analitik. Pengabdian masyarakat ini bertujuan untuk skrining (pemeriksaan) kadar hemoglobin sebagai deteksi dini penyakit anemia dengan metode POCT, mengetahui hubungan antara umur, pendidikan, pekerjaan terhadap kejadian anemia serta sebagai upaya preventif (pencegahan) untuk meminimalisir penyakit anemia. Hasil menunjukkan dari 48 reponden (laki-laki 11 orang), (perempuan 37 orang) bahwa kejadian anemia pada perempuan $40 \%$ lebih besar dibandingkan dengan laki-laki $6 \%$. Jumlah kasus anemia terbanyak terjadi pada umur $\geq 60$ presentase $36,36 \%$ dibandingkan kelompok umur lainnya. Jumlah kejadian anemia terbanyak dengan presentase $46 \%$ pekerjaan Petani dibandingkan pekerjaan lainnya. Jumlah anemia dengan pendidikan sekolah dasar presentase 16,67\% terbanyak dibandingkan dengan pendidikan lainnya. Kesimpulannya tidak terdapat hubungan antara umur, pendidikan, pekerjaan terhadap penyakit anemia bagi masyarakat desa Sumbersono, Mojokerto.
\end{abstract}

Kata kunci: Anemia, Kadar Hemoglobin . POCT, Faktor Anemia

\begin{abstract}
Cases of anemia in Indonesia are still quite high. The results show that the national prevalence of anemia in all age group is $21.70 \%$. While the prevalence of anemia in East Java Province was $5.8 \%$. Anemia is a disease because the number of red blood cells is lower than the normal number. This condition is commonly referred to blood deficiency. Anemia can be detected by measuring of hemoglobin ( $\mathrm{Hb}$ ) levels using the POCT (Point of Care Testing) method. The POCT method is a method that is carried out for a simple examination using a small samples, easy, fast and effective carried out in areas with a number of health facilities such as community health centers, hospitals that are relatively small, especially in community service locations in the village Sumbersono, Mojokerto. The type of method used is analytic observational. This community service activities aims to screening (examining) hemoglobin levels as an early detection of anemia using the POCT method, to find out the relationship between age, education, work and anemic events and as a preventive measure (prevention) to minimize anemia. The results showed there were 48 population, while (11 men), ( 37 women) that the incidence of anemia in women was $40 \%$ greater than $6 \%$ men. The highest number of anemia cases occurred at age $\geq 60$ is $36.36 \%$ compared to other age groups. The highest number of anemia occurrences with $46 \%$ of Farmers' work compared to other occupations. The highest number of anemia with primary school education level is $16.67 \%$ compared to other education levels. Conclution There was no significant correlation between age, educational background, works and anemia cases in community the Sumbersono village, Mojokerto.
\end{abstract}

Keywords: Anemia, Hemoglobin Levels. POCT, Anemia Factor 


\section{PENDAHULUAN}

Anemia adalah masalah kesehatan masyarakat yang mempengaruhi populasi di seluruh dunia. Prevalensi anemia berdasarkan World Health Organization (WHO) dari data yang dikumpulkan tahun 1993 hingga 2005 diperkirakan sekitar 1,6 miliar orang (seperempat dari populasi dunia) menderita anemia (Petry et al., 2016). Prevalensi anemia di Indonesia masih cukup tinggi hasil menunjukkan bahwa angka prevalensi anemia secara nasional pada semua kelompok umur adalah 21,70 $\%($ Priyanto, 2018). Sedangkan prevalensi anemia di Provinsi Jawa Timur sebesar 5,8 $\%$. Angka tersebut masih dibawah target nasional yaitu sebesar 28\%. WHO mengklasifikasi prevalensi anemia suatu daerah berdasarkan tingkat masalah yaitu berat $\geq 40 \%$, sedang $20 \%-39,9 \%$, ringan 5 $\%-19,9 \%$ dan normal $\leq 4,9 \%$ (Natalia, Sumarmi, \& Nadhiroh, 2018).

Anemia artinya "kurang darah" didefinisikan sebagai penurunan jumlah total hemoglobin atau jumlah sel darah merah yang menyebabkan pasokan oksigen tidak mencukupi untuk memenuhi kebutuhan fisiologis tubuh (Arulprakash \& Umaiorubahan, 2018). Hemoglobin adalah suatu metaloprotein yaitu protein yang mengandung zat besi di dalam sel darah merah yang berfungsi sebagai pengangkut oksigen dari paru-paru keseluruh tubuh (Fitriany \& Saputri, 2018).

Penyebab anemia dapat diklasifikasi menjadi dua jenis. Penyebab pertama adalah berkurangnya kadar hemoglobin dalam darah atau terjadinya gangguan dalam pembentukan sel darah merah dalam tubuh. Berkurangnya sel darah merah secara signifikan dikarenakan terjadinya perdarahan atau hancurnya sel darah merah secara berlebihan. Penyebab kedua dipengaruhi pembentukkan hemoglobin dalam darah karena efek keganasan yang tersebar seperti kanker, radiasi, obat-obatan, zat toksik serta penyakit menahun yang melibatkan gangguan pada ginjal dan hati, infeksi serta defisiensi hormon endokrin
(Priyanto, 2018). Penyebab anemia dapat diketahui dengan melakukan pendekatan diagnostik secara bertahap melalui pengumpulan data klinis, pemeriksaan fisik dan tes di laboratorium.

Deteksi dini melalui diagnosis anemia dapat dilakukan dengan mengukur kadar hemoglobin $(\mathrm{Hb})$ dengan peralatan POCT (Point of Care Testing). Metode POCT merupakan metode pemeriksaan sederhana menggunakan sampel dalam jumlah sedikit, mudah, cepat serta efektif untuk dilakukan di daerah-daerah dengan jumlah fasilitas kesehatan seperti puskesmas dan rumah sakit yang relatif sedikit khususnya, di lokasi pengabdian masyarakat di Desa Sumbersono, Mojokerto provinsi Jawa Timur. Pemeriksaan kadar hemoglobin didasarkan pada standar kadar normal anemia perempuan sebesar $12-15 \mathrm{mg} / \mathrm{dl}$ dan laki-laki sebesar 13,5-17 mg/dl (Faatih, Sariadji, \& Susanti, 2017).

Kegiatan pengabdian masyarakat bertujuan untuk skrining (pemeriksaan) kadar hemoglobin sebagai deteksi dini penyakit anemia dengan menggunakan metode POCT; mengetahui hubungan antara umur, pendidikan, pekerjaan terhadap kejadian anemia dan sebagai upaya preventif (pencegahan) untuk meminimalisir penyakit anemia serta mendukung program pemerintah \& WHO untuk menurunkan prevalensi anemia sebesar $50 \%$ pada tahun 2025.

Pemeriksaan kadar hemoglobin ( $\mathrm{Hb})$ dilakukan dengan stript test, data primer diperoleh melalui kuisioner dan wawancara sedangkan kegiatan preventif (pencegahan) untuk meminimalisir penyakit anemia dilakukan dengan memberikan informasi kepada masyarakat desa Sumbersono yang positif (+) anemia untuk meningkatkan kebutuhan nilai gizi, memberikan informasi terkait gaya hidup sehat dan bersih.

\section{METODE}

Metode yang digunakan dalam pengabdian masyarakat adalah observasional analitik menggunakan sampel sebanyak 48 
responden masyarakat desa Sumbersono Mojokerto. Pengabdian masyarakat ini dilakukan pada bulan Mei 2019. Pemilihan sampel dilakukan berdasarkan random sampling. Teknik pengambilan data primer dilakukan melalui wawancara tentang riwayat kesehatan responden dan kuisioner sedangkan pemeriksaan kadar hemoglobin $(\mathrm{Hb})$ dilakukan dengan menggunakan metode POCT (Point of Care Testing).

Pengukuran kadar hemoglobin $(\mathrm{Hb})$ dengan metode POCT yang dilakukan melalui pemeriksaan menggunakan strip test. Pengambilan sampel darah responden diletakkan pada strip $\mathrm{Hb}$ kemudian strip $\mathrm{Hb}$ tersebut dimasukkan pada alat Cek $\mathrm{Hb}$, maka secara otomatis nilai kadar $\mathrm{Hb}$ akan terdeteksi pada alat. Kategori kadar hemoglobin normal pada untuk perempuan $12-15 \mathrm{mg} / \mathrm{dl}$ sedangkan laki-laki 13,5 -17 $\mathrm{mg} / \mathrm{dl}$ (Priyanto, 2018).

\section{HASIL DAN PEMBAHASAN}

Hasil pemeriksaan kadar hemoglobin ( $\mathrm{Hb})$ pada masyarakat desa SumbersonoMojokerto, dapat dilihat pada gambar 1.

Gambar 1.

Pie chart status penderita anemia

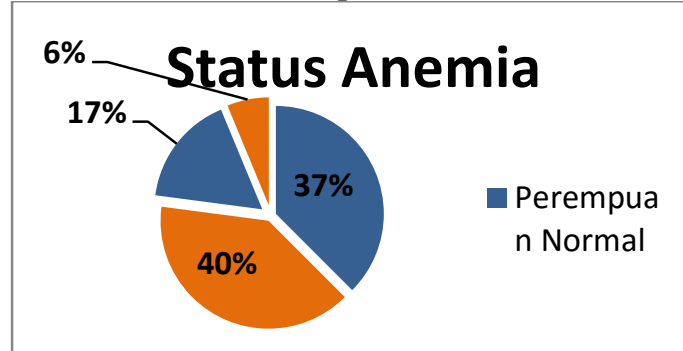

Jumlah total responden 48 orang. 11 responden berjenis kelamin laki-laki dan 37 responden berjenis kelamin perempuan. Pemeriksaan kadar hemoglobin ( $\mathrm{Hb})$ perempuan kategori anemia sebesar $40 \%$ sedangkan laki-laki kategori anemia sebesar $6 \%$. Perempuan lebih rentan terkena anemia dikarenakan perempuan memiliki kadar hemoglobin dan hematokrit (persentase jumlah sel darah merah per 100 $\mathrm{ml}$ volume darah) yang lebih rendah dari pada laki-laki. Selain itu perempuan membutuhkan asupan zat besi yang lebih tinggi daripada laki-laki karena perempuan mengalami kondisi seperti menstruasi, kehamilan, menyusui dan menopause (Shabrina, Andisa, 2019). Tingkat anemia yang terjadi pada laki-laki meningkat secara menoton dengan bertambahnya umur (Le, 2016).

Analisis serta gambaran karakteristik responden yang didasarkan pada umur dapat dilihat pada tabel 1 .

Tabel 1.

Karakteristik responden berdasarkan umur

\begin{tabular}{|c|c|c|}
\hline $\begin{array}{c}\text { Kelompok } \\
\text { Umur (Tahun) }\end{array}$ & $\begin{array}{c}\text { Jumlah } \\
\text { Anemia }\end{array}$ & Persentase \\
\hline$\leq 20$ & 4 & $18,18 \%$ \\
\hline $20-30$ & 1 & $4,55 \%$ \\
\hline $30-40$ & 1 & $4,55 \%$ \\
\hline $40-50$ & 1 & $4,55 \%$ \\
\hline $50-60$ & 7 & $31,82 \%$ \\
\hline$\geq 60$ & 8 & $36,36 \%$ \\
\hline
\end{tabular}

Berdasarkan pada tabel 1 hasil pemeriksaan kadar hemoglobin $(\mathrm{Hb})$ menunjukkan bahwa umur termuda dalam pemeriksaan anemia adalah 19 tahun dengan jenis kelamin perempuan memiliki persentase anemia sebesar 18,18 \%. Kelompok umur 50-60 tahun memiliki persentase sebesar 31,82\% dan kelompok umur $\geq 60$ tahun memiliki persentase terbesar yaitu $36,36 \%$. Umur merupakan usia individu yang terhitung mulai saat dilahirkan sampai saat ini. Semakin cukup umur maka tingkat daya tangkap dan pola pikir seseorang akan lebih matang dalam berfikir, sehingga pengetahuan yang diperolehnya semakin membaik. Ada faktor lain yang juga mempengaruhi kejadian anemia, yaitu faktor dasar (sosial, ekonomi, pengetahuan, pendidikan dan budaya). Faktor langsung (pola konsumsi tablet Fe, penyakit infeksi dan perdarahan) (Priyanto, 2018).

Penyakit anemia sering terjadi pada kelompok umur yg lebih tua. Berdasarkan penelitian yang dilakukan (Stauder, Valent, \& Theurl, 2018) bahwa kadar hemoglobin 
$(\mathrm{Hb})$ menurun dengan bertambahnya usia. Berdasarkan konsep patofisiologis penyakit yang mendasari anemia pada umur yang lebih tua yaitu: Anemia yang didasarkan pada defisiensi zat besi, folat dan vitamin B12. Selain itu penyebab khas dan umur lanjut usia (lansia) yang menderita anemia adalah gangguan penyakit yang menyerang individu lansia, serta gangguan eksresi fungsi ginjal yg merupakan faktor penyebab anemia (Stauder et al., 2018). Pemeriksaan kadar hemoglobin dan tingkat pendidikan dapat dilihat (grafik 1).

\section{Grafik 1.}

Hasil pemeriksaan kadar hemoglobin $(\mathrm{Hb})$ terhadap tingkat pendidikan

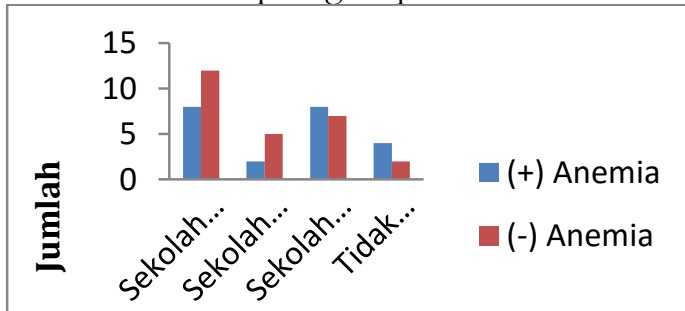

Tingkat Pendidikan

Grafik 1 menunjukkan positif anemia sebanyak 8 orang $(16,67 \%)$ tingkat pendidikan SD, 2 orang $(4,17 \%)$ tingkat pendidikan SMP, 8 orang $(16,67 \%)$ tingkat pendidikan SMA, dan 4 orang $(8,33 \%)$ tidak mengetahui tingkat pendidikannya. Diperoleh informasi bahwa tidak terdapat hubungan yang signifikan antara tingkat pendidikan dengan kejadian penyakit anemia(Purbadewi \& Ulvie, 2013).

Tingkat pendidikan merupakan salah satu faktor yang dapat mempengaruhi daya untuk menyerap dan memahami pengetahuan yg didapatkan oleh seseorang. Semakin banyak dilakukan penyerapan informasi, maka semakin banyak pula pengetahuan yang didapatkan termasuk pengetahuan kesehatan (Lukman, 2018).

Pengetahuan memiliki peran penting dalam pemeliharaan status anemia. Tingkat pendidikan,pengetahuan tentang kesehatan, serta status gizi (nutrisi) mempengaruhi kualitas hidup terkait pencegahan anemia maupun pengobatan anemia (Nimbalkar,
Patel, Thakor, \& Patni, 2017).

Pengetahuan merupakan salah satu faktor yang menstimulasi atau merangsang terhadap terwujudnya sebuah perilaku kesehatan. Apabila mengetahui, memahami anemia serta cara preventif (pencegahan) anemia maka akan mempunyai perilaku kesehatan yang baik dengan harapan dapat terhindar dari berbagai akibat resiko terjadinya anemia. Perilaku kesehatan yang demikian berpengaruh terhadap penurunan kejadian penyakit anemia (Purbadewi \& Ulvie, 2013).

Faktor lainnya yang mempengaruhi anemia adalah pendapatan rumah tangga yang rendah, dapat di lihat dalam gambar 2 (Roshan, Navipor, \& Alhani, 2014).

Gambar 2.

Pie chart tingkat pendidikan, status pekerjaan dengan anemia.

\section{Tingkat Pendidikan, Pendapatan dengan...}

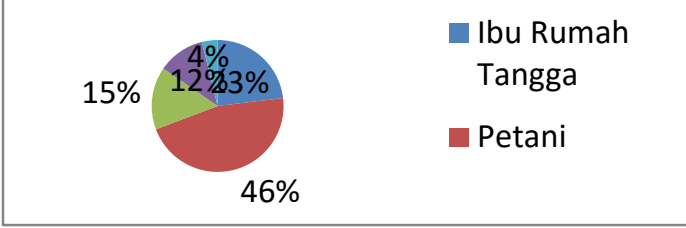

Faktor lainnya yang mempengaruhi kadar hemoglobin yaitu:

a. Geografi (tinggi rendahnya suatu daerah)

Makhluk hidup yang tinggal di dataran tinggi lebih cenderung aktif memproduksi sel darah merah untuk meningkatkan suhu tubuh dan lebih aktif mengikat kadar oksigen dibandingkan yang tinggal didataran rendah. Hemoglobin makhluk hidup yang tinggal di pesisir cenderung memiliki hemoglobin yang lebih rendah sebab tubuh memproduksi sel darah merah dalam keadaan normal.

\section{b. Nutrisi}

Makanan yang dikonsumsi banyak mengandung $\mathrm{Fe}$ atau zat besi maka sel darah 
yang diproduksi akan meningkat sehingga hemoglobin dalam darah meningkat.

\section{c. Faktor Kesehatan}

Kesehatan sangat mempengaruhi kadar hemoglobin dalam darah. Jika kesehatan dalam kondisi yang baik maka kadar hemoglobin akan selalu dalam keadaan normal.

\section{d. Faktor Genetik dan Penyakit Kronis}

Genetik seperti Ibu hamil yang menderita anemia beresiko terhadap gangguan tumbuh kembang janin dan beresiko terhadap persalinan.

Hasil dari pemeriksaan kadar hemoglobin $(\mathrm{Hb})$ pada masyarakat desa Sumbersono, Mojokerto adalah masyarakat mengetahui apakah dirinya positif terkena penyakit anemia atau tidak.

\section{Gambar 3.}

Pemeriksaan kadar hemoglobin
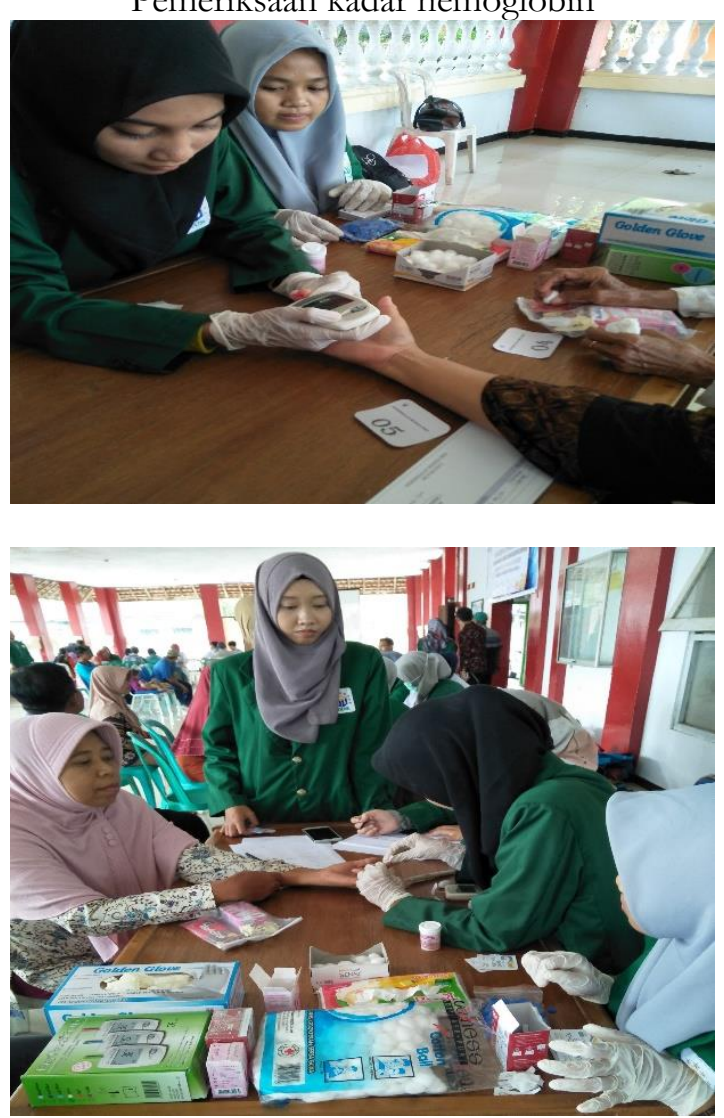

Sumber: Dokumentasi Pribadi

\section{KESIMPULAN}

Kegiatan pengabdian masyarakat berupa pemeriksaan kadar hemoglobin dengan metode POCT (Point of Care Testing) Sebagai Deteksi Dini Penyakit Anemia di Desa Sumbersono - Mojokerto. Pemeriksaan kesehatan yang dilakukan dalam kegiatan ini untuk mendiagnosis awal apakah masyarakat khususnya,di desa SumbersonoMojokerto positif atau negatif terkena penyakit anemia.

Hasil dari 48 responden dapat disimpulkan bahwa perempuan menderita anemia $40 \%$ lebih besar dibandingkan dengan laki-laki $6 \%$. Jumlah responden dengan kasus anemia terjadi pada umur $\geq 60$ presentase $36,36 \%$. Serta status pekerjaan petani dengan jumlah anemia terbanyak dibandingkan pekerjaan lainnya seperti (Ibu Rumah tangga, mahasiswa, pegawai pemerintah dan swasta). Tidak terdapat hubungan antara umur, tingkat pendidikan, pekerjaan dengan penyakit anemia pada masyarakat desa Sumbersono - Mojokerto. Untuk kegiatan preventif (pencegahan) dalam rangka meminimalisir penyakit anemia dilakukan dengan memberikan informasi kepada masyarakat desa Sumbersono yang positif $(+)$ anemia agar meningkatkan kebutuhan nilai gizi, memberikan informasi terkait gaya hidup sehat dan bersih.

\section{DAFTAR PUSTAKA}

Arulprakash, N., \& Umaiorubahan, M. (2018). A study of the prevalence of anemia and associated sociodemographic factors in pregnant women in Port Blair, Andaman and Nicobar Islands. Journal of Family Medicine and Primary Care, 7(6), 12481252.

https://doi.org/10.4103/jfmpc.jfmpc Faatih, M., Sariadji, K., \& Susanti, I. (2017). Penggunaan alat pengukuran hemoglobin di puskesmas polindes dan pustu. Jurnal Penelitian Dan Pengembangan Pelayanan Kesehatan, 8. 
Fitriany, J., \& Saputri, A. I. (2018). Anemia Defisiensi Besi. Jurnal Averrous, 4(2). https://doi.org/10.24893/jkma.2.1.14 $0-145.2007$

Le, C. H. H. (2016). The prevalence of anemia and moderate-severe anemia in the US population (NHANES 20032012). PLoS ONE, 11(11), 1-14. https://doi.org/10.1371/journal.pone. 0166635

Natalia, S., Sumarmi, S., \& Nadhiroh, S. R. (2018). Cakupan Anc Dan Cakupan Tablet Fe Hubungannya Dengan Prevalensi Anemia Di Jawa Timur. Media Gizi Indonesia, 11(1), 70. https://doi.org/10.20473/mgi.v11i1.7 $0-76$

Nimbalkar, P. B., Patel, J. N., Thakor, N., \& Patni, M. (2017). Impact of educational intervention regarding anaemia and its preventive measures among pregnant women: an interventional study. International Journal of Reproduction, Contraception, Obstetrics and Gynecology, 6(12), 5317. https://doi.org/10.18203/23201770.ijrcog20175137

Petry, N., Olofin, I., Hurrell, R. F., Boy, E., Wirth, J. P., Moursi, M., ... Rohner, F. (2016). The proportion of anemia associated with iron deficiency in low, medium, and high human development index countries: A systematic analysis of national surveys. Nutrients, 8(11), 117.https://doi.org/10.3390/nu811069 3

Priyanto, L. D. (2018). The Relationship of Age, Educational Background, and Physical Activity on Female Students with Anemia. Jurnal Berkala Epidemiologi, 6(2), 139. https://doi.org/10.20473/jbe.v6i2201 8.139-146
Purbadewi, L., \& Ulvie, Y. S. N. (2013). Hubungan Tingkat Pengetahuan Tentang Anemia Dengan terhadap terwujudnya sebuah perilaku kesehatan. Apabila ibu hamil mengetahui dan accidental sampling yaitu teknik, 2(April), 31-39.

Roshan, F. S. N., Navipor, H., \& Alhani, F. (2014). The Effect of Education-Based Intervention Using Small Group Discussion in Empowering Adolescent Girls to Prevent Iron Deficiency Anemia. Patient Safety and Quality Improvement Journal, 2(4), 151-155. https://doi.org/10.22038/psj.2014.33 99

Shabrina, Andisa. (2019). Kenapa Wanita Lebih Rentan Mengalami Anemia?, Fromhttps://hellosehat.com/pusatkesehatan/anemia/penyebab-anemiapada-wanita/

Stauder, R., Valent, P., \& Theurl, I. (2018). Anemia at older age: etiologies, clinical implications, and management. Blood, 131(5), 505514.https://doi.org/10.1182/blood2017-07-746446 